\title{
Viral Innovation: Integration via Sustainability \& Enterprise Excellence
}

\author{
Rick L. Edgeman and Jacob Kjær Eskildsen
}

ICOA, Aarhus University, Aarhus, Denmark

\begin{abstract}
Enterprises face mounting challenges in three generic sustainability domains that form the basis of the so-called triple bottom line: economic sustainability, societal sustainability, and environmental sustainability. In most instances, it is the primacy of economic sustainability that is emphasized since an enterprise that is not economically secure does not survive.

Despite the importance of sustainability's economic dimension, increasing regulatory requirements taken together with societal demands are forcing enterprises to address both their impact on the natural environment and their contribution to society. Indeed, taken together these considerations form a sort 'holy trinity' that are necessary as both singular and joint considerations for enterprises striving to be continuously relevant and responsible. Environmental impacts and societal contributions can take many forms and thus far the environmental and societal challenges facing enterprises have, when considered comprehensively, outpaced the capability of enterprises to successfully address them.

Since enterprises must be economically sustainable, an enterprise excellence approach supported by various international quality award models and criteria is herein recommended. This is augmented with emphasis on strategic, high-speed integration and deployment of sustainable innovation and innovation for sustainability. The goal in taking this approach is to aid organizations in their quest for continuously relevant and responsible actions and results.
\end{abstract}

Keywords: Enterprise Excellence, Innovation, Sustainability.

\section{Introduction}

Enterprises strive to be economically sustainable. In doing so, they either contribute to or detract from environmental and social sustainability. Sustainability is hence multi-dimensional with formulations that include the familiar triple-bottom-line and BEST models. Any assessment regimen for these models include Biophysical/Environmental, Business/Economic, and Societal dimensions with the BEST model adding a Technological dimension that refers predominantly to infrastructure, that is, to the builtenvironment.

Integration across these sustainability dimensions is challenging, but can be facilitated by substantial sustainabilitydriven innovation with innovation being broadly construed. As commonly perceived, the word "innovation" often implies highvelocity change. Adding enterprise-wide emphasis on innovation alongside appropriately tuned and attuned human

Copyright (C) 2012 Rick L. Edgeman and Jacob Kjær Eskildsen. This is an open access article distributed under the Creative Commons Attribution License unported 3.0, which permits unrestricted use, distribution, and reproduction in any medium, provided that original work is properly cited. Contact author: Rick L. Edgeman Email: rledge@asb.dk 
capital to this velocity yields what is henceforth called "viral innovation".

Evidence of growing global emphasis on environmental and social sustainability is provided by the United Nations Global Compact

(http://www.unglobalcompact.org/), the Pearl Initiative in the Middle East (http://www.pearlinitiative.org), and a new initiative aimed at innovating the field of sustainability itself recently launched by the Interdisciplinary Center of Organizational Architecture (ICOA: http://icoa.au.dk/) at Aarhus University in Denmark. In varied forms each of these, as well as several other initiatives, aim to rapidly advance, disseminate, and embed highly effective sustainability policies and practices into enterprises.

Similarly, abundant testimony of the importance of sustainability to enterprises is found in the strategic plans and at the websites of firms large and small; manufacturing or service; local, regional, or international. Relevant websites for wellknown enterprises that embrace sustainability are provided in Table 1 . Though many enterprises emphasize environmental and social sustainability, sustainability of the enterprise itself is of primary importance with innovation cited increasingly as a driver thereof that manifests differently across business sectors, enterprises, and sustainability dimensions. Many enterprises have tried, but failed, to build a viable business case to support emphasis of environmental and social sustainability initiatives in their strategy (Kiron, et. al., 2012). The business case may in fact, however, be a simple one: stakeholder or governmental agency demand that, if ignored, can detrimentally impact corporate reputation and marketplace performance.

Table 1. Websites for Well-Enterprises that Embrace Sustainability

\begin{tabular}{|c|c|}
\hline ENTERPRISE & WEBSITE \\
\hline Boeing & http://www.boeing.com \\
\hline British Petroleum & http://www.bp.com \\
\hline Canon Corporation & http://www.canon.com/ \\
\hline Dow Chemical & http://www.dow.com/sustainability/ \\
\hline Dupont & http://www.dupont.com/ \\
\hline Grundfos & $\begin{array}{l}\text { http://www.grundfos.com/about-us/sustainability- } \\
\text { responsibility/strategies-and-policies/innovation-intent.html/ }\end{array}$ \\
\hline GE & http://www.ge.com/ \\
\hline Maersk & $\begin{array}{l}\text { http://www.maersk.com/Innovation/SustainableInnovation/Pages/Su } \\
\text { stainableInnovation.aspx }\end{array}$ \\
\hline Microsoft & http://www.microsoft.com/ \\
\hline Monsanto & http://www.monsanto.com/ \\
\hline Novozymes & http://www.novozymes.com/en/sustainability/pages/default.aspx/ \\
\hline Oracle & http://www.oracle.com/ \\
\hline Raytheon & http://www.raytheon.com/responsibility/stewardship/sustainability \\
\hline Vestas & http://www.vestas.com/ \\
\hline
\end{tabular}

It is thus that we examine environmentaland-social-sustainability-focused viral innovation as a means of contributing to overall enterprise sustainability and, more broadly, enterprise excellence. We do this after first obtaining a more general overview of sustainability. 


\section{Sustainability and the VISE Triad}

The origin of most sustainability constructs stem from a macro-level view of development provided in the report of a commission chaired by Dr. Gro Harlem Bruntland, former Director General of the World Health Enterprise (WHO) and former Prime Minister of Norway. The report provides a definition (World Council on Economic Development, 1987: 43-44) that is reasonably well captured by the phrase "lean, green, ethical and real" where:

- Lean refers predominantly to conservation of non-environmental resources;

- Green is associated with conservation of non-renewable natural resources, wise use of renewable natural resources, and limitation of environmental footprint;

- Ethical is related to commitment to and practice of social equity and justice, community involvement and contribution, and positive regard for and treatment of the enterprise's human capital; and

- Real implies lean, green, and ethical practice with concomitant results.

A more familiar expression of sustainabilitybased development is:

Sustainable development seeks to meet the needs and aspirations of the present without compromising the ability to meet those of the future.

This calls for sustaining the overall integrity of the ecosystem, alleviation of human suffering, and extending to all people an opportunity to satisfy their desires for a better life.

However humanitarian alleviation of poverty or other forms of human suffering may be, business growth almost always precedes societal income growth that enables alleviation. Further, enterprises impact both ecosystems and the human condition, hence either enabling or inhibiting the ability both individually and collectively of people to improve their lives. Given the impact and influence of enterprises on and in ecosystems and society, it is vital to consider possible enterprise contributions and movement toward broad-based sustainability.

Financially based approaches to enterprise sustainability with central focus on shareholder value are widely practiced. Expansion of enterprise sustainability to include environmental and societal domains is, however, often perceived as anathema to financially-based models since economic measures such as shareholder value are generally regarded as contradicting, rather than complementing considerations such as natural resource consumption, waste production and management, climate change, and biodiversity.

A key challenge then, is to identify or create and exercise synergies among economic, environmental, and social performance. In many cases, innovation may be the mechanism by which such synergies can be leveraged and in that sense innovation can provide an integrating thread weaving through "lean, green, ethical, and real".

This effort is supported by jointly focusing on multiple bottom lines, rather than singular emphasis of financial results alone. The caveat, however, is that joint optimization of multiple bottom lines typically leads to suboptimization of any or all constituent elements (Hensler and Edgeman, 2002). An argument in favor of applying enterprise excellence models, principles, and assessment regimens is their encouragement of innovation and joint optimization across the triple bottom line elements, hence providing a platform for innovation-driven sustainability.

There are many enterprise excellence definitions, models, and associated assessment regimens and most explicitly embed and either overtly or implicitly assesses sustainability across the triple- 
bottom line dimensions. These models include the European Quality Award (http://www.efqm.org/), America's Baldrige National Quality Award (http://www.nist.gov/baldrige/), the BEST Model (Edgeman and Hensler, 2001), and the ISO 9000 series of standards purposes these are sufficiently indistinct and the perspective herein modifies one provided by Edgeman, et. al. (1999) that has been generally used in discussions of the BEST Model, that is:

Enterprise excellence is a consequence of balancing both the competing and complementary interests of key stakeholder segments to increase the likelihood of superior and sustainable competitive positioning and hence long-term enterprise success. This is accomplished through an integrated approach emphasizing innovation, operational, customer-related, financial, (http://www.iso.org/iso/qmp/). For present

marketplace, societal, and environmental performance.

In this formulation innovation is not regarded as a pre-condition to, but rather an enabler of enterprise excellence and hence of enterprise sustainability so that innovation contributes to creation and maintenance of competitive advantage. Indeed, many consider the only true sustainable competitive advantage to be the ability to innovate, that is, to learn faster and more rapidly implement improved products, processes, systems, and problem solutions than one's competitors. We thus have:

Rapid (Learning + Implementation) $\Rightarrow$ Innovation (1)

More extensively we can express a relationship between the trinity of innovation, sustainability, and enterprise excellence (ISE-triad), as:

Sustainable Enterprise

Innovation $\diamond$ Rapid (Learning + Implementation) $\Rightarrow$ Competitive $\Rightarrow$ Excellence Advantage

"Rapid" is emphasized in both (1) and (2) to highlight the velocity of marketplace change, associated stimuli and associated results, and the necessity of transforming learning enterprises (Senge, 1990) into fast or rapid learning enterprises (RLO) and, in turn, into rapid or viral innovators. When innovation is viral, ISE becomes VISE.

\section{Innovation and the Sustainability Super Cell}

Merlin, the wizard of Sir Thomas Malory's $15^{\text {th }}$ century Arthurian Legend, differed from all other people in that he lived backwards in time so that surprises were not in results, but rather in the journey to those results, since the "end is known from the beginning". Our circumstances differ from Merlin's in that it is not the "end" itself that is known, but only the path thus far and forecasts of the future, many of which are dire.
Those dire forecasts have driven societal, governmental, and competitive pressures and fortified demands that enterprises become environmentally and socially responsible. Nussbaum (2011) summarized this by stating "We face huge forces of disruption, the rise and fall of generations, the spread of social media technologies, the urbanization of the planet, the rise and fall of nations, global warming, and overpopulation. economic, social, and political systems in a once-in-a-century kind of way".

Enterprises unable to harness these forces face potentially disastrous results, but for those successfully able to integrate sustainability into their business models and strategy these forces have supplied the energy to create substantial marketplace opportunities. Integration of this sort, however, necessitates innovation on many Together these forces are eroding our 
levels and while execution of well-formulated and well-deployed innovation-driven sustainability strategy provides a sensible, even compelling way of doing business for the enterprises of today and tomorrow, we are nevertheless reminded that many enterprises have failed to build a business case for sustainability. Cornell University professor Stuart Hart explains this situation as follows, implicitly suggesting that innovation provides a solution (Kiron, et. al., 2012).

"It comes down to a question of organizational design and will. We need to create new commercial models, new business models in underserved space with small, distributed point of use technologies, which don't fit the current business model, current culture or traditional investment horizons. It requires a different investment approach. It has to be protected ... It comes down to a question of how do you make this more systemic? How do you build it in, make it part of the DNA of what large corporations are designed to do?"

Organizational or enterprise culture can be thought of as "the way we do things around here"; it is the engineering of "the DNA of viral innovation" into enterprise culture that is addressed throughout the remainder of this piece. It is apparent that whether enterprises can see a clear path to profit or competitive advantage from them, they are taking this DNA to heart by adopting sustainability initiatives at a significant rate in recent years. The tipping point for any given enterprise doing so resides at the intersection of promise and necessity (Kiron, et. al., 2012).

While such intersections are in large unmapped, they provide opportunities to identify or generate relationships between economic performance and meaningful measures of environmental and social performance. Generating such relationships is itself an act of innovation as is new business model generation (Osterwalder and Pigneur, 2010; Skarzynski and Gibson, 2008).
Sustainability has been identified as an emerging megatrend or "super cell", meaning that it is forcing persistent and foundational changes in how enterprises compete (Lubin and Esty, 2010). Lubin and Esty further identified key common strategies and value creation stages - all of which involve or leverage innovation - that enabled enterprises to emerge from prior megatrends as market leaders. By extension the "struggling enterprises" of Kiron, et. al. (2012) may successfully adapt and deploy strategies learned from such enterprises. The strategies and value creation stages cited by Lubin and Esty are:

- Focusing on reducing cost, risks, and waste and delivering proof-of-value;

- Redesigning selected products, processes, or business functions to optimize their performance and hence progress from doing old things in new ways to doing new things in new ways;

- Driving revenue growth by integrating innovative approaches into core strategies;

- Differentiating the enterprise value proposition through new business models that use these innovations to enhance enterprise culture, brand leadership, and other intangibles to secure durable competitive advantage.

The positioning of innovation here is not innovation in the broad sense, but is instead at the point of greatest leverage: in core strategies producing more rapid and more pervasive deployment throughout the enterprise leading in turn to impact that is both more broad and deep - keys to viral innovation.

Further, objectives cited by Lubin and Esty (2010) include fundamental change in the corporate culture, including the way in which innovation drives sustainability to attain brand leadership. Eccles, et. al. (2011) documented numerous enterprise behavior and performance benefits of inculcating an enterprise culture of sustainability. 
Table 2: Stages and Innovation Opportunities on the Path to Culture of Sustainability

\begin{tabular}{|c|c|}
\hline STAGE & INNOVATION OPPORTUNITIES \\
\hline $\begin{array}{l}\text { View } \\
\text { Compliance as } \\
\text { an Opportunity }\end{array}$ & $\begin{array}{l}\text { - Use compliance to induce the enterprise and its partners to } \\
\text { experiment with sustainable technologies, materials, and processes. }\end{array}$ \\
\hline $\begin{array}{l}\text { Making Value } \\
\text { Chains } \\
\text { Sustainable }\end{array}$ & $\begin{array}{l}\text { - Develop sustainable sources of raw materials and components. } \\
\text { - Increase the use of clean energy sources such as wind and solar } \\
\text { power. } \\
\text { - Find innovative uses for returned products. }\end{array}$ \\
\hline $\begin{array}{l}\text { Design } \\
\text { Sustainable } \\
\text { Products \& } \\
\text { Services }\end{array}$ & $\begin{array}{l}\text { - Apply techniques such as bio-mimicry in product development. } \\
\text { - Developing compact and eco-friendly packaging. } \\
\text { - Develop centralized technologies such as cloud computing that } \\
\text { reduce overall local need for physical resources. }\end{array}$ \\
\hline $\begin{array}{l}\text { Develop New } \\
\text { Business } \\
\text { Models }\end{array}$ & $\begin{array}{l}\text { - Develop new delivery technologies that change value-chain } \\
\text { relationships in significant ways. } \\
\text { - Create monetization models that relate to services rather than } \\
\text { products. } \\
\text { - Devise business models that combine digital and physical } \\
\text { infrastructures. } \\
\text { - Overtly incorporate a co-creation oriented innovation process at the } \\
\text { interface of the enterprise and society (Edgeman and Eskildsen, } \\
\text { 2012). }\end{array}$ \\
\hline $\begin{array}{l}\text { Create Next- } \\
\text { Practice } \\
\text { Platforms }\end{array}$ & $\begin{array}{l}\text { - Build business platforms that enable customers and suppliers to } \\
\text { manage energy in radically different ways. } \\
\text { - Develop products that won't need water in categories traditionally } \\
\text { associated with it, such as cleaning products. } \\
\text { - Design technologies that will allow industries to use the energy } \\
\text { produced as a byproduct. } \\
\text { - Explicitly identify secondary and tertiary uses of products, thus } \\
\text { extending their usage and hence the product life cycle. } \\
\text { - Leverage technology that significantly reduces demand for physical } \\
\text { resource, e.g., replace physical books with technology such as the } \\
\text { Apple iPad. }\end{array}$ \\
\hline
\end{tabular}

In "Why innovation is now the key driver of sustainability", Nidumolu, et. al. (2009) identified five stages of change on the path toward an enterprise culture of sustainability, along with stage-specific innovation opportunities. These stages and opportunities provide the basic content of Table 2, where identified innovation opportunities have been significantly expanded to incorporate considerations such as bio-mimicry (Benyus, 2002), co-creation at the enterprise-culture interface, and leverage of new technologies not cited by Nidumolu, et. al. (2009).
The stages and identified innovation opportunities are highly consistent with the work of Lubin and Esty in that the approach emphasized is in each instance overtly "lean and green", calls for development of new business models, and emphasizes innovation-driven sustainability.

Firms capable of capitalizing on an innovation-driven path to sustainability must themselves not only be set on the path, but must be populated by sustainabilityconcerned, innovation-oriented, individuals essentially two among seven elements of the 
System of Profound Consciousness (SYPROCON) elaborated by Edgeman and Fraley (2008). Those individuals, while truly individuals, must also be effective collaborators and co-creators, an idea wellcaptured by famed physicist, David Bohm (Jaworski, 1996: 80-81) as: "at present people create barriers between each other by their fragmentary thought. Each one operates separately. When these barriers have dissolved, then there arises one mind, where they are all one unit, but each person retains his or her own individual awareness."

Collaboration and co-creation must also be cultivated and the mindset of such individuals along with characteristics of individuals with the ability to "take innovation viral" are next discussed, followed by a discussion of involvement of likeminded such people in innovation-driven sustainability efforts.

\section{Taking Sustainability-Driven Innovation Viral}

In a 2008 Harvard Business Review contribution, Tim Brown, the president and CEO of IDEO, America's leading innovation and design firm, identified five key traits of innovative thinkers or, as he referred to them, "design thinkers". Substantially modified to incorporate sustainability considerations, those traits are summarized below:

Empathetic Orientation: Individuals with a general innovation bent imagine the world from multiple perspectives, including those of colleagues, clients, end users, and both current and prospective customers. This anthropologic or people-first approach allows innovative thinkers to imagine solutions that are inherently desirable and meet explicit or latent needs. This trait is in fact highly consistent with the "empathetic listening" habit of Covey (1989). Spanning the stakeholder spectrum and anthropomorphizing the environment to include its "voice" allows not only for societal sensitivity, but also to at least some extent incorporation of "the environment as stakeholder". In this sense innovation can drive joint-optimization across the triple bottom line.

Innovation through Integration: This practice demands integration of analytic processes with consideration of all salient aspects of complicated problems, even contradictory aspects, and so create novel solutions that go beyond and dramatically improve upon existing ones. This is critical to innovation-driven sustainability since societal and environmental considerations themselves are commonly regarded as contradictory to economic ones. In particular, integration of sustainable innovation and innovation for sustainability is critical.

Optimism: This mind-set offsets the constraints of a given problem with the belief that there is at least one potential solution superior to existing alternatives that can both be identified or created and successfully implemented. Adding a sustainability emphasis to this mind-set increases the likelihood that an innovative solution with strong sustainability characteristics is developed.

Experimentalism: Significant innovation only rarely results from incremental improvements, although it often results from a series of such improvements. Innovators pose questions and push boundary conditions in creative ways that advance in unexplored directions. Sustainability is widely regarded as imperative not only to the enterprise, but also to society and the natural environment, so that experimentalism's boundary challenging approach may be not only useful, but necessary.

Collaboration and Co-Creation: Echoing the thoughts of Bohm (Jaworski, 1996) and adapted to innovation are those of Brown (2008): "The increasing complexity of products, services, and experiences has replaced the myth of the lone creative genius with the reality of the enthusiastic interdisciplinary collaborator." 
Commonly innovators have depth of experience in, long functioned at the intersection of, and collaborated across multiple and diverse disciplines. Actively engaging and listening to those for whom we are innovating as we ascertain and elaborate their needs produces socially sensitive cocreation, about which noted design anthropologist Anna Kirah (Jokisalo, 2008) asserts:

"Change does not happen until different areas within the same companies learn to speak the same language as the culture of the people they are innovating for and that they can speak together across disciplines" (Jokisalo, 2008: 1).
Integrating
such
multi-disciplinary
experience
with socially-and-

environmentally-focused innovation may be referred to as socio-ecological cocreation and provides an exceptional means for enterprises to integrate social and environmental sustainability considerations into both their policies and practices in ways that are also fundamentally aligned with economic sustainability of the enterprise.

Brown (2008) describes a path for integrating innovation into enterprise strategy and practice that, if modified to reflect sustainability considerations, is a path toward socio-ecological co-creation that is also highly consistent with enterprise excellence approaches. This modified path is summarized in Table 3, after which the notion of "taking sustainability-driven innovation viral" is addressed. 
Table 3: A Path to Socio-Ecological Co-Creation. Adapted from Brown (2008)

\begin{tabular}{|c|c|}
\hline FOCUS & INNOVATION STRATEGY \& ACTIONS \\
\hline $\begin{array}{l}\text { Innovation from } \\
\text { the Start }\end{array}$ & $\begin{array}{l}\text { Engage in the innovation process before any direction has been set and } \\
\text { develop a larger set of potential solutions than would otherwise be explored. } \\
\text { By expanding the potential solution portfolio a greater number of solution } \\
\text { fragments is generated that will typically lead to a better overall solution. } \\
\text { Actively involve an "eco-voice" representing environmental considerations. }\end{array}$ \\
\hline $\begin{array}{l}\text { People-Centered } \\
\text { Innovation }\end{array}$ & $\begin{array}{l}\text { Beyond business and technology considerations driving financial } \\
\text { sustainability, innovation should factor in human behavior, needs, and } \\
\text { preferences. People-centered design thinking captures unexpected insights } \\
\text { and produces innovation that more precisely reflects consumer wants and } \\
\text { societal needs. }\end{array}$ \\
\hline $\begin{array}{l}\text { Rapid } \\
\text { Development }\end{array}$ & $\begin{array}{l}\text { Consistent with being a RLO (rapid learning enterprise), expect rapid } \\
\text { experimentation and prototyping. Measure progress with creativity metrics } \\
\text { such as average time to first prototype. This supports the need to rapidly } \\
\text { advance sustainable solutions. }\end{array}$ \\
\hline $\begin{array}{l}\text { Focus on Co- } \\
\text { Creation }\end{array}$ & $\begin{array}{l}\text { Expand the innovation ecosystem by engaging in co-creation with customers } \\
\text { and the culture. Doing so supports creation of societally acceptable and } \\
\text { sustainable solutions. }\end{array}$ \\
\hline $\begin{array}{l}\text { Big and Small: } \\
\text { The Innovation } \\
\text { Portfolio }\end{array}$ & $\begin{array}{l}\text { Not unlike the Nobel Prize for Economics winning strategy of investment } \\
\text { portfolio diversification, manage an innovation portfolio that stretches from } \\
\text { short-term incremental ideas to long-term revolutionary ones. Expect } \\
\text { business units to drive and fund incremental innovation, but be willing to } \\
\text { initiate revolutionary innovation from the top. This approach to innovation } \\
\text { ensures that innovation is part of the fabric of the enterprise, contributing to } \\
\text { its economic sustainability. By requiring that a significant subset of these } \\
\text { innovation ideas also have positive environmental or societal sustainability } \\
\text { ramifications, a more comprehensive innovation view of sustainability } \\
\text { emerges in the organization that simultaneously addresses enterprise } \\
\text { excellence, sustainability, and innovation that is sometimes incremental in } \\
\text { nature and sometimes viral in magnitude. }\end{array}$ \\
\hline $\begin{array}{l}\text { Pace of } \\
\text { Innovation } \\
\text { Budgeting }\end{array}$ & $\begin{array}{l}\text { While innovation often occurs rapidly, the route to commercialization is often } \\
\text { unpredictable and must navigate the intellectual property jungle. } \\
\text { Cumbersome budgeting cycles constrain the pace of innovation. Be prepared } \\
\text { to reallocate funds as projects proceed and innovation teams learn more } \\
\text { about opportunities. This approach to budgeting improves enterprise agility } \\
\text { and hence to respond to consumer and societal needs. Agility is rewarding. }\end{array}$ \\
\hline $\begin{array}{l}\text { Talent } \\
\text { Capitalization }\end{array}$ & $\begin{array}{l}\text { Build human capital by hiring people with interdisciplinary orientations. } \\
\text { Similarly, provide innovation, design, and sustainability training strategically } \\
\text { throughout the enterprise. People with more conventional design } \\
\text { backgrounds can push solutions far beyond your expectations. In conjunction } \\
\text { with a sustainability focus, increasing the innovation capacity of the } \\
\text { enterprise ensures that more creative and more diverse potential problem } \\
\text { solutions surface and is explored with many such solutions being related to } \\
\text { one or more sustainability dimensions. }\end{array}$ \\
\hline $\begin{array}{l}\text { Design for the } \\
\text { Cycle }\end{array}$ & $\begin{array}{l}\text { Many enterprises rotate employees more rapidly than the typical design-to- } \\
\text { implementation cycle. It is wise to plan assignments so innovation and design } \\
\text { thinkers go from inspiration to ideation to implementation. Experiencing the } \\
\text { full cycle builds better judgment and creates great long-term benefits for the } \\
\text { enterprise, including better understanding of how innovation in a specific } \\
\text { product, process, or system impacts across all sustainability dimensions. }\end{array}$ \\
\hline
\end{tabular}


How though, do we leverage the opportunities sustainability initiatives can offer? In his best-selling book, The Tipping Point (2008), author Malcolm Gladwell defines a tipping point as "the moment of critical mass, the threshold, the boiling point" and states that "ideas and products and messages and behaviors spread like viruses do." Gladwell described three rules of epidemics which we state here as the vital few, message impact, and the context factor along with three agents of change referred to as connectors, mavens, and salesmen as tipping points.

The Message Impact is judged by the specific content of a message, idea, or innovation. This must yield memorable impact for viral innovation to result. With respect to the Context Factor, human behavior is sensitive to and strongly influenced by its environment in the same what that epidemics are sensitive to the conditions and circumstances of the times and places in which they occur.

The Vital Few: In keeping with the familiar Pareto Principle the success of any kind of social epidemic or virus is heavily dependent on the involvement of a vital few people who are particularly adept at exercising selected social skills to strengthen and spread the innovation virus. These are essentially the connectors, mavens, and salesmen of Gladwell (2008) and are described as follows:

- Connectors are in some sense those individuals responsible for greasing the enterprise's innovation engine and do so by forging vital connections between people, ideas, and things. Apart from the likelihood of being collaborators themselves, Connectors are individuals who are highly skilled at facilitating collaboration of and co-creation by others. Like Brown's innovators (Brown, 2008), the success of Connectors is their ability to span many different worlds and is a function of something intrinsic to their personality, some combination of curiosity, self-confidence, sociability, and energy (Gladwell, 2008).

- Mavens are essentially problem-solvers, whether the problems to be solved are their own, those of others, or enterprise ones. Mavens relentlessly accumulate and share knowledge and information in both planned and spontaneous ways in an effort to solve problems. Essentially Mavens begin word-of-mouth epidemics with their knowledge, social skills, and communication ability - they are information brokers.

- Salesmen are charismatic people with powerful negotiation skills and power of persuasion whose words, demeanor, confidence, and enthusiasm tend to compel others to agree with them. As such, salesmen are those who are able to marshal and organize the support of others, and move them in a unified direction, thus creating a focused critical mass of human capital in the enterprise.

By analogy, Connectors are the synapses, Mavens the energy, and Salesmen the acetylcholine bridging enterprise synapses and transmitting the energy in its brain, thus triggering enterprise-wide innovation. The social and environmental context is both fertile for and necessitates sustainability, but it is the impact or business case that has often been inadequate. So that the vital few the Connectors, Mavens, and Salesmen and hence the enterprise - have often been on another trajectory that has commonly been poorly aligned with environmental and social sustainability imperatives.

\section{Conclusion}

Sustainability has been identified as an emerging megatrend or super cell. We have seen that there are distinct linkages between innovation, sustainability, and enterprise excellence - the ISE triad. At issue is how to exploit those linkages in ways that jointly promote social, environmental, and enterprise sustainability since, as previously 
noted, many enterprises have been unable to make a strong business case for sustainability.

That is, of course, a way of stating that such enterprises have failed to demonstrate that social and environmental sustainability initiatives contribute to their financial health to a greater extent than alternative initiatives. In that regard, the focus of the present work has been pointed forward to a forward that will enable the business case to be made with that way forward being one driven by innovation. Additionally, given the scale and scope of many problems faced by enterprises and society, it is important the velocity of innovation is at the needed level that is, "that it takes innovation viral".

We have also learned that enterprises that have emerged triumphantly from prior megatrends have followed an established path, with stages that are congruent with the principles and values of sustainability, and throughout which innovation is manifest. Enterprises that integrate innovation throughout their strategy and practices, that are peopled by individuals with strong innovative mindsets and strong sustainability orientations are themselves well-positioned to be triumphant, in part by deploying an innovation-driven sustainability strategy.

It is one thing to state that innovation is a key enabler of sustainability in general and enterprise sustainability more specifically and it is a second thing to be peopled by highly innovative individuals. It is a third, and quite other thing to successfully systematize and integrate innovation into enterprise strategies, practices, and culture in ways that promote environmental and social sustainability, while also supporting its economic sustainability. It is with such an approach that we conclude.

Grayson, et. al. (2008), present "a vision of corporate sustainability that places an emphasis on innovation as the means to add value, not just to the bottom line, but to the environment and society at large." The authors built on such initiatives as the Dow Jones Sustainability Index, Tomorrow's Global Company, and SustainAbility, all of which look beyond shareholder value by also considering social and environmental impacts. Such approaches are consistent with the approaches taken by, e.g., the balanced scorecard and enterprise excellence models such as those behind the European Quality Award and the Baldrige Quality Award in that large amount of non-financial information are incorporated into enterprise performance assessment.

The approach developed by Grayson, et. al. is called S2AVE (Shareholder and Social Added Value with Environment Restoration). S2AVE underscores that enterprises can successfully, profitably, and simultaneously address all three triple bottom line elements, becoming increasingly agile and innovative as they do so. The steps of S2AVE are:

- Make innovating for sustainability a part of enterprise vision;

- Formulate a strategy with sustainability at its core;

- Integrate sustainability into all parts of your business;

- Walk the talk by emphasizing actions over rhetoric;

- Set up a board level body with the power to make sustainability matter;

- Set firm rules;

- Engage and gain stakeholder support;

- Use people power;

- Join key networks;

- Think beyond reporting by aligning all business systems with the enterprise's vision of sustainability. 
For deployment purposes, the S2AVE steps can be elaborated and customized by a given enterprise, with emphasis on deployment being rapid or viral. The stages and innovation opportunities cited in Table 1 that are supportive of creating an enterprise culture of sustainability, and the foci, strategies, and actions on the path to socioecological co-creation cited in Table 2 should be incorporated in such elaboration and customization efforts. Similarly, actively populating the enterprise's human capital with people rich in the personality traits common to innovators can be of great benefit to the enterprise, and this HR strategy is accentuated my making sure that the enterprise's human capital has a healthy blend and distribution of connectors, mavens, and salesmen (Gladwell, 2008).

It is not solely emphasis of all three triple bottom line elements that is important. Rather, these must also be in reasonable balance and - in the ideal - jointly optimized in accordance with applicable criteria and constraints. Such strategies, of course, must and can be successfully devised and deployed (Edgeman and Hensler, 2005). Part of successful deployment, given the imperative nature of sustainability, is to demand viral innovation from the enterprise.

It is perhaps appropriate that in closing we heed words of wisdom from the late master of innovation and co-founder of Apple Computer, Steve Jobs (1955-2011): "Innovation is the difference between leaders and followers", to which we might add that "innovating for sustainability is the difference between leaders and responsible leaders".

\section{References}

Benyus, J. (2002). 'Biomimicry: Innovation Inspired by Nature,' HarperCollins, New York, NY.

Brown, T. (2008). "Design Thinking," Harvard Business Review, June, 84-92.

Covey, S. (1989). 'Seven Habits of Highly Effective People,' Free Press, New York, NY.
Eccles, R. G., Ioannou , I. \& Serafeim, G. (2011). "The Impact of a Corporate Culture of Sustainability on Corporate Behavior and Performance," Harvard Business School Working Paper 12-035, November 25, 2011. Harvard Business School, Boston, MA.

Edgeman, R., Dalgaard, S., Dahlgaard, J. \& Scherer, F. (1999). 'Leadership, Business Excellence Models and Core Value Deployment,' Quality Progress, 32 (10), 4954.

Edgeman, R. \& Eskildsen, J. (2012). 'PeopleCentered Innovation: Co-Creation \& Profound Consciousness,' Proceedings of the 18th International Business Information Management Association (IBIMA), ISBN: 9780-9821489-7-6, 9-10 May 2012, Istanbul, Turkey.

Edgeman, R. L. \& Fraley, L. A. (2008). "A system of Profound Consciousness: Building Beyond Deming," Total Quality Management and Business Excellence, 19 (7/8), 683-707.

Edgeman, R. L. Hensler, D. A. (2001). "The AO Chronicle: earth@omega or sustainability@alpha?," The TQM Magazine, 13 (2), 83-90.

Edgeman, R. L. \& Hensler, D. A. (2005). "QFD and the BEST Paradigm: Deploying Sustainable Solutions," World Review of Science, Technology and Sustainable Development, 2 (1), 49-59.

Gladwell, M. (2000). 'The Tipping Point: How Little Things Can Make a Big Difference,' Little Brown Publishers, New York.

Grayson, D., Rodriguez, M. A., Lemon, M., Jin, Z., Slaughter, S. \& Tay, S. (2008). "A New Mindset for Corporate Sustainability," British Telecommunications plc and Cisco Systems, London, UK.

Hensler, D. A. Edgeman, R. L. (2002). "Modeling BEST Business Excellence: The Beginning," Measuring Business Excellence, 6 (2), 49-54. 
Jaworski, J. (1996). 'Synchronicity: The Inner Path of Leadership,' Berrett-Koehler Publishers, Inc., San Francisco, CA.

Jokisalo, E. (2008). "Innovation is for Everyone. Learning is for Everyone: An Interview with Anna Kirah," eLearning Papers, No. 8. ISSN: 1887-1542 [Online], [Retrieved October 20, 2009] www.elearningpapers.eu

Kiron, D., Kruschwitz, N., Haanaes, K., \& von Streng Velken, I. (2012). "Sustainability Nears a Tipping Point," Sloan Management Review, Winter 2012. [Online], [Retrieved December 15, 2011], http://sloanreview.mit.edu/themagazine/2012winter/53213/sustainability-nears-atipping-point/

Lubin, D. A. \& Esty, D. C. (2010). "The Sustainability Imperative," Harvard Business Review, May, 2-10.

Nidumolu, R., Prahalad, C. K. \& Rangaswami, M. R. (2009). "Why Sustainability is Now the Key Driver of Innovation," Harvard Business Review, September, 57-64.

Nussbaum, B. (2011). 'Design Thinking is a Failed Experiment: So What's Next?,' April 6, Fast Company Design, New York, NY.

Osterwalder, A. \& Pigneur, Y. (2010). Business Model Generation: A Handbook for Visionaries, Game Changers, and Challengers, John Wiley \& Sons, New York, NY.

Skarzynski, P. \& Gibson, R. (2008). Innovation to the Core: A Blueprint for Transforming the Way Your Company Innovates, Harvard Business Press, Boston, MA.

Senge, P. (1990). "The Fifth Discipline: The Art \& Practice of the Learning Organization," Currency Doubleday, New York, NY.
World Commission on Environment and Development (1987). "Our Common Future," (aka the WCED Brundtland Report). 43-44, Oxford University Press, Oxford, UK. 